\title{
Determination of the Optimum Incubation \\ Time for In Vitro Digestion of Rice Straw
}

\author{
Tatsushi Inoue, Koji Toyokawa and Kaizo Tsubomatsu \\ Faculty of Agriculture, Hirosaki University \\ Hirosaki-shi 036
}

(Received September 8, 1986)

\begin{abstract}
It is considered that rice straw which contains a large proportion of characteristic insoluble components is digested more slowly than forages of high quality, when in vitro digestion methods are adopted. This study aimed to determine the optimum incubation time in both the rapid cellulase method and the artificial rumen method, and the following results were obtained.

1. The in vitro dry matter digestibility (IVDMD) determined by the rapid cellulase method was much increased with incubation time up to two hours, but was still lower than the in vivo dry matter digestibility.

2. IVDMD determined by the artificial rumen method was not stabilized over 72 hours of incubation, and also it varied with the rumen fluid inocula taken from wethers under different feeding regimes.

3. IVDMD determined after the two-hour incubation by the rapid cellulase method and also that after the 72-hour incubation by artificial rumen method were highly correlated with in vivo dry matter digestibility. Correlation coefficients were $0.954(P<0.01)$ and $0.899(P<0.01)$, respectively.

4. It is concluded that the rapid cellulase method would be proper to estimate the nutritive value of rice straw in vitro, and the optimum incubation time would be two hours in applying this method to rice straw.
\end{abstract}

Jpn. J.Zootech. Sci., 58 (6) : 483-489, 1987

Key words : incubation time, in vitro dry matter digestibility, artificial rumen method, rapid cellulase method, rice straw.

For the purpose of estimating the nutritive value of forages for ruminants, it has been shown that in vitro digestion methods can be applied. The artificial rumen method described by McDougALL ${ }^{1)}$ is well-known, but a new method using enzymes has been reported by $\mathrm{ABE}$ et al. ${ }^{2,3,4,5)}$ Furthermore, FuruYA et al. ${ }^{6)}$ simplified the method of ABE et al. and developed the rapid cellulase method. However, the forages used in these studies were usually good quality hay, and only a few data for straws are available.

ToyoKawA et $a l^{8,9)}$ applied the rapid cellulase method and the artificial rumen method to rice straw, and reported that these methods were sufficient to estimate the nutritive value of rice straw. However, since rice straw is rich in characteristic indigestible components, it is desirable to determine the optimum incubation time in these in vitro digestion methods. This study was conducted to determine the optimum incubation time by the successive measurement of in vitro dry matter digestibility 
Inoue, ToYoKaWA and Tsubomatsu

(IVDMD) of rice straw by the rapid cellulase method and the artificial rumen method.

\section{Materials and Methods}

\section{Rapid cellulase method}

Because of its simplicity and the low protein content of rice straw, the method described by FuruYa et al. ${ }^{6)}$ was adopted. Seven groups of rice straw harvested around Hirosaki were tested. Two of the seven groups were damaged by the cold weather in 1983 . These straws were dried and ground through a $1 \mathrm{~mm}$ Wileymillscreen, and then 0.4-0.5 g of ground straw was incubated in a $50 \mathrm{ml}$ tube with $50 \mathrm{ml}$ of 196 cellulase solution (Onozuka $\mathrm{R}-10$ in $\mathrm{pH} 4.0$ buffer) by shaking (100 r.p.m.) the incubator for 1, 2, 3, 4, 6 and 8 hours and consecutive IVDMD were measured.

Artificial rumen method

To carry out the incubation, urea-containing McDougall's buffer proposed by Horir et al. was used. Two kinds of rumen fluid inoculum were used : Inoculum A was prepared by mixing almost the same volumes of rumen fluid taken from two fistulated wethers which were fed $400 \mathrm{~g} /$ day of wheat bran and $500 \mathrm{~g} /$ day of orchardgrass hay, and given rice straw, mineral salts and water ad libitum. Inoculum B was prepared by the same way and using the same wethers as inoculum $\mathrm{A}$, but the donors were given $400 \mathrm{~g} /$ day each of wheat bran and orchardgrass hay and additionally allowed to graze on an orchardgrass-pasture, with free access to mineral salts and water. The eight groups of rice straw were sampled around Hirosaki : five of them were cut at the fully ripe stage and three were cut at the tillering stage. These straws were processed in the same way as that in the rapid cellulase method and $0.4-0.5 \mathrm{~g}$ of substrates were incubated for 48,72 and 96 hours.

In vivo digestion trial

In vivo digestibilities were determined for all tested straws by the total collection method using three or four wethers. To avoid residues, the amount of rice straw provided was restricted to $21 \mathrm{~g} / \mathrm{W}^{0.75} \mathrm{~kg}$.

Chemical analysis

General composition, acid detergent fiber (ADF), neutral detergent fiber (NDF), cellulose and lignin were determined by official methods ${ }^{11)}$, and crude silica was determined by the method of OKUTA et al. ${ }^{12)}$

\section{Results}

\section{Rapid cellulase method}

Chemical composition, in vivo dry matter digestibility, structural carbohydrates and insoluble components of tested rice straws are shown in Table 1 and in Table 2, respectively. Cold-damaged straws had a higher crude protein content and a lower crude ash content than normal. In vivo dry matter digestibilities varied from 48. 1$67.7 \%$, and the average was $57.0 \%$, a value higher than usual. Although fractions of NDF and NDF-ADF, which are related to hemicellulose, were slightly higher, other components were at an ordinary level. 


\section{In vitro Digestion of Rice Straw}

Fig. 1 shows the change in time of IVDMD determined by the rapid cellulase method. The value increased rapidly and reached a plateau within two hours of incubation, but was much lower than the in vivo dry matter digestibility (Table 1).

\section{Artificial rumen method}

Table 3 shows the chemical composition of rice straw tested in this trial and their

Table 1. Chemical composition of rice straw used in the experiment by the rapid cellulase method and the in vivo dry matter digestibility.

\begin{tabular}{|c|c|c|c|c|c|c|}
\hline \multirow{2}{*}{ Division } & \multicolumn{5}{|c|}{ Chemical composition of dry matter (\%) } & \multirow{2}{*}{$\begin{array}{c}\text { Dry matter } \\
\text { digestibility } \\
\mathscr{9 6}\end{array}$} \\
\hline & $\begin{array}{l}\text { Crude } \\
\text { protein }\end{array}$ & $\begin{array}{l}\text { Crude } \\
\text { fat }\end{array}$ & $\begin{array}{l}\text { Crude } \\
\text { fiber }\end{array}$ & $\begin{array}{l}\text { Crude } \\
\text { ash }\end{array}$ & NFE & \\
\hline Mean & 6.3 & 1.6 & 30.1 & 15.8 & 46.2 & 57.0 \\
\hline Max. & 10.2 & 2.0 & 32.3 & 19.3 & 52.3 & 67.7 \\
\hline Min. & 4.1 & 1.3 & 28.2 & 11.2 & 43.6 & 48.1 \\
\hline
\end{tabular}

Table 2. Structural carbohydrates and insoluble components of rice straw used in the experiment by rapid cellulase method experiment.

\begin{tabular}{lccccccc}
\hline \hline & \multicolumn{6}{c}{ Contents in dry matter (\%) } \\
\cline { 2 - 8 } Divison & NDF & ADF & $\begin{array}{l}\text { NDF- } \\
\text { ADF }\end{array}$ & Lignin & $\begin{array}{c}\text { ADF- } \\
\text { lignin }\end{array}$ & $\begin{array}{c}\text { Crude } \\
\text { silica }\end{array}$ & $\begin{array}{c}\text { Lignin +crude } \\
\text { silica }\end{array}$ \\
\hline Mean & 69.4 & 40.6 & 28.8 & 9.4 & 31.2 & 10.8 & 20.2 \\
Max. & 72.0 & 44.7 & 31.0 & 11.0 & 34.7 & 14.1 & 23.1 \\
Min. & 65.4 & 36.4 & 27.3 & 8.6 & 27.8 & 6.1 & 14.7 \\
\hline
\end{tabular}

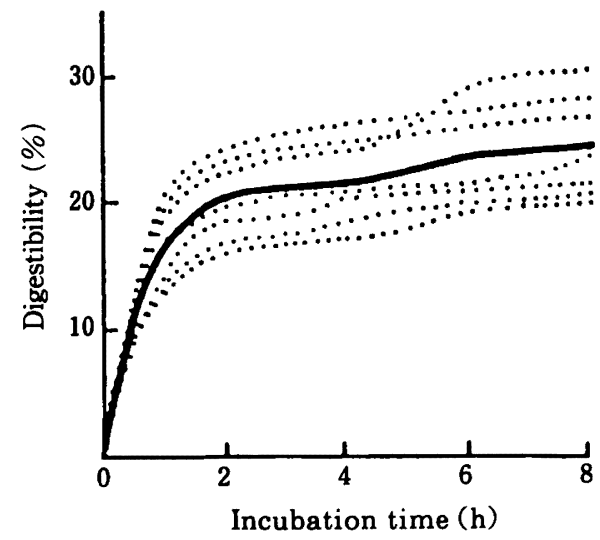

Fig. 1. Changes in in vitro digestibility of rice straw determined by the rapid cellulase method

- mean ….individual 
InOue, Toyokawa and Tsubomatsu

in vivo dry matter digestibilities. Table 4 shows results of the analysis for structural carbohydrates and insoluble components.

Fully ripe straw had an usual chemical composition. Tillering straw had higher contents of crude protein and crude fat, and especially the former content was almost twice as much as usual straw. Little difference was observed in the in vivo dry matter digestibility between fully ripe straw and tillering straw. This might be attributed to similar contents of crude fiber, crude ash and NFE, which are the main components of rice straw. Contents of structural carbohydrates and insoluble components were almost similar at two growth stages, but all components were slightly higher in fully ripe straw than in tillering except a hemi-cellulose fraction (NDF-ADF).

Fig. 2 shows the change in time of IVDMD determined by the artificial rumen method. A clear difference appeared according to the inoculum used, and IVDMD was higher at any time and more linear when rumen fluid $\mathrm{A}$ was inoculated. In vitro digestion of fully ripe straws proceeded until 72 hours of incubation when rumen fluid $B$ was inoculated, and this trend was also seen in the case of tillering straws. The magnitude of variation of individual IVDMD was much larger when rumen fluid B was inoculated than when $\mathrm{A}$ was inoculated. These facts suggest that the source of the rumen fluid inoculum has an influence on the digestibility of rice straw. However,

Table 3. Chemical composition of rice straw used in the artficial rumen method experiment and the in vivo dry matter digestibility

\begin{tabular}{llcccccc}
\hline \hline \multirow{2}{*}{$\begin{array}{l}\text { Stage of } \\
\text { harvesting }\end{array}$} & Division & \multicolumn{4}{c}{ Chemical composition of dry matter (\%) } & \multirow{2}{*}{$\begin{array}{c}\text { Dry matter } \\
\text { digestibility }\end{array}$} \\
\cline { 3 - 7 } & & $\begin{array}{l}\text { Crude } \\
\text { protein }\end{array}$ & $\begin{array}{l}\text { Crude } \\
\text { fat }\end{array}$ & $\begin{array}{l}\text { Crude } \\
\text { fiber }\end{array}$ & $\begin{array}{l}\text { Crude } \\
\text { ash }\end{array}$ & NFE & \% \\
\hline \multirow{3}{*}{ Fully ripe } & Mean & 4.6 & 1.6 & 30.9 & 17.0 & 45.9 & 47.3 \\
& Max. & 5.3 & 1.8 & 34.9 & 18.9 & 47.7 & 53.1 \\
& Min. & 4.3 & 1.3 & 26.5 & 15.2 & 42.7 & 37.7 \\
& Mean & 9.9 & 2.3 & 28.2 & 17.2 & 42.3 & 48.1 \\
Tillering & Max. & 11.1 & 2.5 & 30.4 & 17.6 & 42.6 & 51.3 \\
& Min. & 7.8 & 2.0 & 27.0 & 16.9 & 41.8 & 44.5 \\
\hline
\end{tabular}

Table 4. Structural carbohydrates and insoluble components of rice straw used in the artificial rumen method experiment.

\begin{tabular}{|c|c|c|c|c|c|c|c|c|}
\hline \multirow{2}{*}{$\begin{array}{l}\text { Stage of } \\
\text { harvesting }\end{array}$} & \multirow{2}{*}{ Division } & \multicolumn{7}{|c|}{ Contents in dry matter (\%) } \\
\hline & & NDF & $\mathrm{ADF}$ & $\begin{array}{l}\text { NDF- } \\
\text { ADF }\end{array}$ & Lignin & $\begin{array}{l}\text { ADF- } \\
\text { lignin }\end{array}$ & $\begin{array}{l}\text { Crude } \\
\text { silica }\end{array}$ & $\begin{array}{l}\text { Lignin + crude } \\
\text { silica }\end{array}$ \\
\hline \multirow{3}{*}{ Fully ripe } & Mean & 67.7 & 42.0 & 25.2 & 9.7 & 32.3 & 13.5 & 23.4 \\
\hline & Max. & 73.4 & 46.5 & 26.9 & 11.5 & 35.0 & 15.7 & 24.7 \\
\hline & Min. & 61.8 & 36.6 & 23.8 & 7.9 & 27.4 & 10.0 & 20.6 \\
\hline \multirow{3}{*}{ Tillering } & Mean & 65.4 & 39.4 & 26.0 & 8.2 & 31.2 & 10.7 & 19.1 \\
\hline & Max. & 68.8 & 41.0 & 29.3 & 8.4 & 33.1 & 11.3 & 19.3 \\
\hline & Min. & 60.7 & 37.5 & 19.7 & 7.9 & 29.1 & 9.9 & 18.8 \\
\hline
\end{tabular}




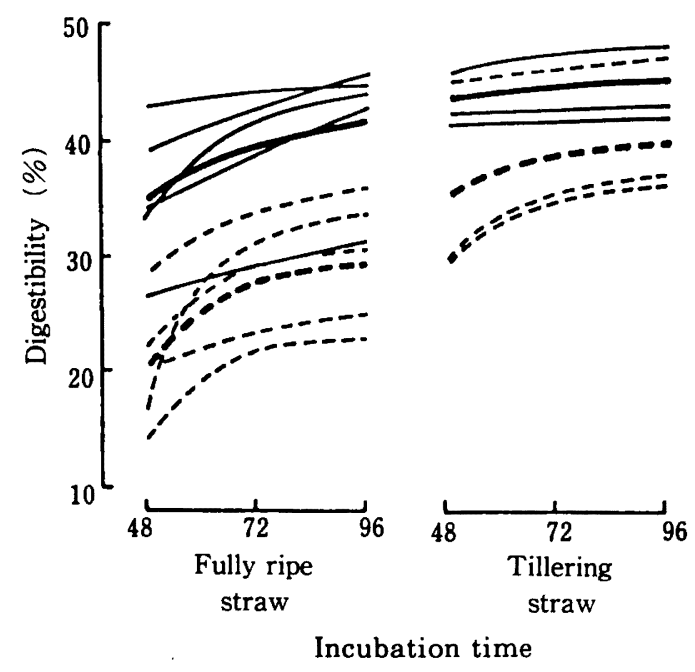

Fig. 2. Changes in in vitro dry matter digestibility of rice straw determined by the artificial rumen method.

- rumen fluid inoculum $A$

-. - - rumen fluid inoculum B

-mean

IVDMD of rice straw was lower than in vivo dry matter digestivility, especially when inoculum B was used.

\section{Discussion}

It is considered that the values of IVDMD determined by both the rapid cellulase and artificial rumen methods will stay at a lower level than the in vivo digestibility even when incubated for a longer time. In the artificial rumen method, the source of the rumen fluid inoculum affected the value of IVDMD. However, the IVDMD determined at the time when digestion ceased in the artificial rumen method was higher than that in the rapid cellulase method which was only a half of the in vivo digestibility.

IVDMD of the rapid cellulase method was very low and stopped increasing after two hours of incubation. The correlation coefficient between IVDMD at this time and in vivo dry matter digestibility was $\mathrm{r}=0.954(\mathrm{P}<0.01)$. Values of IVDMD determined at one and three hours after the incubation have also highly significant correlations with in vivo digestibility, and the correlation coefficients were $r=0.921(P<0.01)$ and $r=0.959(P<0.01)$, respectively. Since the increase of IVDMD almost ceased after two hours of incubation, the two-hour incubation system could be recommended for rice straw as is the case for other forages. According to the rapid cellulase method, the regression equation between IVDMD for the two-hour incubation and the in vivo dry matter digestibility was as follows :

$Y=1.99 X+17.11$ ( $Y$; in vivo dry matter digestibility, $X$; IVDMD) 
Although the authors attempted the two-step method described by ABE et al. ${ }^{2,3,4,5)}$ with the same straws as used in this work, a lower correlation was obtained.

When the artificial rumen method was adopted, the difference in the incubation inoculum or the diet given to the donor affected the value of IVDMD, suggesting that this method is not reliable enough to estimate the nutritive value of rice straw. The consistency of the activity of inoculum is required when this method is adopted. Also, the great increase of IVDMD from 48 to 72 hours of incubation using inoculum $B$ suggests that a longer time is required for rice straw than for forages of higher quality. Therefore, the 72-hour incubation system is recommended to stabilize dry matter digestibility of rice straw. The correlation coefficient between IVDMD of the 72-hour incubation using inoculum $\mathrm{A}$ and the in vivo dry matter digestibility was $\mathrm{r}=0.899(\mathrm{P}<0.01)$, and the regression equation was as follows :

$Y=1.32 X+3.31$ ( $Y$; in vivo dry matter digestibility, $X$; IVDMD)

Furthermore, the correlation between values of IVDMD determined by the artificial rumen method used rumen fluid inoculum $A$ and by the rapid cellulase method was $r=$ $0.889(\mathrm{P}<0.01)$, and the equation was as follows :

$Y=1.26 X+15.32(Y$; IVDMD of artificial rumen method, $X$; IVDMD of rapid cellulase method)

This high correlation suggests that dry matter digestibility of rice straw can be estimated by either of both in vitro methods.

However, in the artificial rumen method, large variations of IVDMD due to the inoculated rumen fluid make it difficult to estimate an in vivo nutritive value of rice straw. In adopting this method, it is necessary to use the inoculum suitable for digesting straws.

Because of its simplicity and stability, the rapid cellulase method is recommended to estimate the dry matter digestibility of rice straw in vitro, and a two-hour incubation is considered to be sufficient for the estimation by this method.

\section{References}

1) McDougall, E.L., Biochem. J., 43:99-109. 1948.

2) Abe, A., S. Hori and K. Kameoka, Jpn. J. Zootech. Sci. $43: 141-145.1971$.

3) Abe, A., S. Horil and K. Kameoka, Jpn. J. Zootech. Sci., 43: 146-154. 1971.

4) Aвe, A., S. HoriI and K. Kameoka, Jpn. J. Zootech. Sci., 43:175-180. 1971.

5) ABE, A. and T. NakUi, J. Japan. Grassl. Sci., $25: 231-240.1979$.

6) Furuya, M., S. Ueda, S. Higuchi and S. Tsutsui, Bull. Hokkaido Nat. Agri., $47: 23-$ 29. 1982.

7) McLeod, M.N. and D.J. Minson, J. Br. Grassl. Soc:, 24 : 244-249. 1969.

8) Toyokawa, K., I. Takayasu and K. Tsubomatsu, J. Japan. Grassl. Sci., $28: 225-233$. 1982.

9) Toyokawa, K., K. Hanzawa, T. Inoue, A. Sakamoto and K. Tsubomatsu, Jpn. Zootech. Sci., $57: 58-64.1986$.

10) Horiı, S., A. AвE, Y. Kon and K. Kameoka, Bull. Nat. Inst. Anim. Ind. Japan. 24 : 99-104. 1971.

11) MoRimoto, H., Experimental method of animal nutrition. 280-297, 346-352. Yokendo. Tokyo. 1971. 


\title{
In vitro Digestion of Rice Straw
}

12) Okuta, A., Experimental method of plant nutrition. 76-78. Asakura. Tokyo. 1959.

稲ワラの in vitro 消化時間の検討

\author{
井上達志・豊川好司・坪松戒三 \\ 弘前大学農学部, 弘前市 036
}

稲ワラに in vitro 消化法を適用する際，その特徽的 難消化性成分檋成から良質の牧草などよりも分解速度が 遅いため，迅速セルラーゼ法ならびに人工ルーメン法の より適当な培羪時間について検討し，次の結果を得た。

1. 迅速セルラーゼ法の in vitro 乾物消化率（以下 IVDMD 之略）は培養 2 時間目まで急速に高まり，そ の後安定傾向を示したが, in vivo 消化率を大きく下ま わった. 2.人工ルーメン法の IVDMD は培養 72 時 間を超えなりれば安定せず，また胃液採取メン羊の飼養
条件によって IVDMD が変動した．3．培養 2 時間目 の迅速セルラーゼ法 IVDMD，および 72 時間目の人工 ルーメン法の IVDMD は in vivo 乾物消化率との間で それぞれ $\mathrm{r}=0.954(\mathrm{P}<0.01), \mathrm{r}=0.899(\mathrm{P}<0.01)$ の高い相関関係を得た。 4. 稲ワラの in vivo 栄養価 值を推定する in vitro 消化試験法として, 培養条件を 一定化できる迅速セルラーゼ法が適切であり，培養時間 は 2 時間が適当と考えられた。

日畜会報，58（6）：483-489, 1987 